\title{
PRIMJENA PARAMETARA STIŠLJIVOSTI U ANALIZI SLIJEGANJA KOMUNALNOG OTPADA
}

\author{
Dragoslav Rakić \\ Univerzitet u Beogradu - Rudarsko-geološki fakultet, docent \\ Jelka Krušić \\ Univerzitet u Beogradu - Rudarsko-geološki fakultet, master student \\ Katarina Andrejev \\ Univerzitet u Beogradu - Rudarsko-geološki fakultet, master student \\ Dušan Lazaroski \\ Univerzitet u Beogradu - Rudarsko-geološki fakultet, master student
}

Sažetak: Da bi se omogućilo točnije modeliranje i numerička simulacija dugotrajnog ponašanja odlagališta otpada, što je veoma važno prilikom projektiranja pokrovnog sustava i zatvaranja odlagališta otpada, neophodno je poznavanje parametara stišljivosti. Za razliku od prirodnog tla, glavnu komponentu ukupnog slijeganja komunalnog otpada predstavlja sekundarna kompresija. Zato je određivanje indeksa sekundarne kompresije $\left(\mathrm{C}_{\alpha}\right)$ ili modificiranog indeksa sekundarne kompresije $\left(\mathrm{C}_{\alpha}{ }^{\prime}\right)$ posebno važno. $U$ radu su prikazani neki od rezultata laboratorijskih ispitivanja uzoraka komunalnog otpada dobiveni u edometarskom uređaju, kao i njihova uloga u analizi slijeganja komunalnog otpada. Ispitivanja su izvršena na umjetno pripremljenim uzorcima, uz uvažavanje preporuka koje se odnose na dimenzije korištenih uređaja i veličinu najvećih frakcija u uzorku (EN 1997-2, ASTM 2007-a, 2007-b). Primjenom različith modela, koji se najčešće koriste za prognozu slijeganja odlagališta komunalnog otpada, izvršena je analiza slijeganja korištenjem dobivenih parametara stišljivosti.

Ključne riječi: komunalni otpad, stišljivost, slijeganje, primarna kompresija, sekundarna kompresija

\section{APPLICATION OF COMPRESIBILLITY PARAMETERS IN THE SETLLEMENT ANALYSIS OF WASTE DISPOSAL}

\begin{abstract}
In order to enable accurate modeling and numerical simulation of long-term behavior of the landfill, which is of great importance in the design of cover systems and closure of the waste disposal, it is necessary to know compressibility parameters. In contrast to the native soil, the main component of the overall settlement of waste is secondary compression. Therefore, the determination of the secondary compression index $\left(\mathrm{C}_{\alpha}\right)$ or modified secondary compression index $\left(\mathrm{C}_{\alpha}{ }^{\prime}\right)$ is especially important. This paper presents some of laboratory results for municipal waste consolidation tests method as well as their role in settlement analysis of waste material. Sample tested was prepared artificially in line with the recommendations for sizes of the apparatus used and the largest particles in a sample (EN 1997-2, ASTM 2007a, 2007b). Different conventional models for prediction of municipal waste settlement were used settlement analysis was performed using the parameters of compressibility.
\end{abstract}

Key words: waste disposal, compressibility, settlement, secondary compression, primary compression 


\section{Uvod}

Uvjet za uspješnu analizu interakcije odlagališta otpada i prirodnog terena, pored poznavanja geotehničkih karakteristika podloge, jest i poznavanje fizičko-mehaničkih parametara komunalnog otpada. Fizičko-mehanička svojstva komunalnog otpada se analiziraju i istražuju primjenom osnovnih metoda i koncepcija koje su razvijene za tlo (uz mnoga ograničenja).

Dosadašnja istraživanja u svijetu su pokazala da je mehaničko ponašanje komunalnog otpada nedovoljno objašnjeno, a neki od razloga za to su: promjenjiv i heterogen sastav otpada koji je po prirodi jako porozan; problematično uzimanje i ispitivanje reprezentativnih uzoraka otpada (dubina i lokacija uzetog uzorka nije uvijek reprezentativna za prosječne osobine otpada u odlagalištu); nepostojanje opće prihvaćene metodologije uzorkovanja i testiranja te velika promjena svojstava koja ovise o vremenu, tj. stupnju razgradnje otpada [1].

Posljednjih godina, u Republici Srbiji se poduzima niz aktivnosti vezanih za izgradnju novih odlagališta komunalnog otpada, sanaciju i rekultivaciju postojećih. Jedan od nezaobilaznih segmenata u sklopu ovih aktivnosti jest provođenje kompleksnih istraživanja samog otpada. U radu su prikazani rezultati laboratorijskih geomehaničkih ispitivanja uzoraka komunalnog otpada dobivenih u edometarskom aparatu, nešto većih dimenzija u odnosu na standardne.

\section{Parametri stišljivosti}

Komunalni otpad je izrazito heterogen i anizotropan pa je određivanje parametara stišljivosti veoma otežano. Po pravilu se teorija konsolidacije, koja se primjenjuje u mehanici tla, primjenjuje i kod komunalnog otpada, pa se koriste isti parametri stišljivosti [1]. Pri tome se koriste konvencionalni edometarski uređaji različitih promjera (od $63 \mathrm{~mm}$ pa do $600 \mathrm{~mm}$ ). Pored laboratorijskih ispitivanja, vrše se i opažanja slijeganja otpada na odlagalištima [2], [3]. Rezultati ispitivanja se najčešće izražavaju preko parametara stišljivosti, $i$ to: indeksa primarne kompresije $C_{c}$ (ili modificiranog indeksa primarne kompresije $C_{c}{ }^{\prime}$ ) i indeksa sekundarne kompresije $C_{\alpha}$ (ili modificiranog indeksa sekundarne kompresije $\mathrm{C}_{\alpha}{ }^{\prime}$ ). Za procjenu slijeganja komunalnog otpada, sve do aktiviranja sekundarne kompresije, koristi se, kao i kod tla, indeks primarne kompresije $C_{c}$, koji se najčešće izražava preko promjene koeficijenta pora.

$$
C_{c}=\frac{\Delta e}{\log \sigma^{\prime}{ }_{i+1}-\log \sigma_{i}^{\prime}}=\frac{\Delta e}{\log \left(\sigma^{\prime}{ }_{i+1} / \sigma^{\prime}{ }_{i}\right)}
$$

gdje je:

$\Delta e$ promjena koeficijenta pora

$\sigma_{i}^{\prime} \quad$ efektivno vertikalno naprezanje za koeficijent pora $e_{i}$

$\sigma_{i+1}^{\prime}$ efektivno vertikalno naprezanje za koeficijent pora $e_{i+1}$.

Određivanje koeficijenta pora komunalnog otpada je dosta složeno pa se iz tog razloga sve češće koristi modificirani indeks primarne kompresije $C_{c}^{\prime}$. On se izražava preko aksijalne deformacije, a ne preko razlike koeficijenta pora:

$$
C_{c}^{\prime}=\frac{\Delta h}{h_{0} \cdot \log \left(\sigma_{i+1}^{\prime} / \sigma_{i}^{\prime}\right)}=\frac{C_{c}}{1+e_{0}}
$$

gdje je:

$e_{0}$ početni koeficijent pora

$h_{0}$ početna visina sloja otpada (uzorka) i

$\Delta h \quad$ promjena debljine sloja otpada, tj. slijeganje otpada (uzorka).

Da bi se procijenilo slijeganje u vremenu nakon završetka primarne faze, koristi se indeks sekundarne kompresije $C_{\alpha}$. On predstavlja odnos smanjenja koeficijenta pora $(\Delta e)$ za jednu jedinicu logaritma vremena $(t)$. 
Određuje se na osnovi aproksimacije sekundarnog dijela krivulje u pravolinijsku, na polulogaritamskom dijagramu $e-\log t$, na osnovi sljedeće jednadžbe:

$$
C_{\alpha}=\frac{\Delta e}{\log t_{2}-\log t_{1}}=\frac{\Delta e}{\log \left(t_{2} / t_{1}\right)}
$$

gdje je:

$t_{1} \quad$ vrijeme na početku sekundarnog slijeganja (vrijeme završetka primarne konsolidacije)

$t_{2}$ vrijeme opažanja (s obzirom na aproksimaciju ravnom linijom, može biti bilo koje vrijeme veće od $t_{1}$ ).

Kao i kod indeksa primarne kompresije, tako se i u ovom slučaju alternativno uvodi modificirani indeks sekundarne kompresije $\mathrm{C}_{a}{ }^{\prime}$, koji se može izraziti preko aksijalne deformacije na sljedeći način:

$$
C_{\alpha}^{\prime}=\frac{\Delta h}{h_{0} \cdot \log \left(t_{2} / t_{1}\right)}=\frac{C_{\alpha}}{1+e_{0}}
$$

U tablici 1 [4], objedinjene su prikazane vrijednosti indeksa i modificiranog indeksa primarne i sekundarne kompresije koje je prezentiralo tridesetak autora, uključujući i vrijednosti koje su dobivene ovim istraživanjima. Može se primijetiti da se vrijednosti dosta razlikuju i da većina autora daje dosta široke intervale. Jedan od razloga za ovako izraženo rasipanje rezultata mogao bi biti način pripreme uzorka, odnosno, različite početne vrijednosti koeficijenta poroznosti i zapreminske težine, ali i primjena različitih vrijednost normalnih naprezanja tijekom ispitivanja.

Također, treba napomenuti da su autori primjenjivali i različite metodologije tijekom ispitivanja. Tako su pojedini autori vršili kratkotrajna ispitivanja, a opterećenja tijekom jednog ciklusa trajala su od nekoliko sati do nekoliko dana. Nasuprot tome, u nekim slučajevima vrijeme jednog ciklusa opterećenja iznosilo je više mjeseci pa i do godinu dana. S druge strane, neki rezultati dobiveni su na malom broju uzoraka, a neki na preko 30 uzoraka. Pored toga, razlikovali su se i uređaji u kojima su vršena ispitivanja, jer su osim konvencionalnih edometarskih uređaja, korišteni i specijalni uređaji koji su uključivali i mogućnost simuliranja dugotrajnog procesa biodegradacije.

\section{Priprema uzoraka i postupak ispitivanja}

Za komunalni otpad još uvijek ne postoji međunarodno prihvaćena standardna procedura uzorkovanja i ispitivanja. Razlog tomu treba tražiti u izrazitoj heterogenosti otpada (po sastavu, veličini i obliku frakcija, različitim svojstvima pojedinih materijala) čije se komponente često „prepliću“, a neke trpe i vlačna naprezanja. Zato se uglavnom ispitivanja vrše na umjetno pripremljenim uzorcima, vodeći računa o vlažnosti, zbijenosti, postotnom sadržaju i obliku pojedinih komponenti otpada. Pored toga vrši se i usitnjavanje pojedinih komponenti otpada, kako bi se osigurao odgovarajući odnos granulometrijskog sastava i dimenzija korištenog uređaja.

Za potrebe ovih istraživanja korišten je otpad različite starosti, uzet iz jednog aktivnog odlagališta otpada koje se trenutačno koristi (Novi Sad), kao i iz jednog odlagališta otpada koje je zatvoreno (Ada Huja u Beogradu). Materijal je prethodno homogeniziran, izmiješan $i$ usitnjen kako bi se dobila zadovoljavajuća veličina frakcija. Maksimalna veličina čestica na pripremljenim uzorcima iznosila je $4 \mathrm{~cm}$, uz napomenu da je manji maseni dio plastičnih frakcija (ne više od 7\%) sadržavao i izdužene - jednodimenzionalne čestice, s dužinom ne većom od 8 $\mathrm{cm}$. Primjereno ovim uvjetima i karakteristikama komunalnog otpada, ispitivanja su obavljena u edometarskom uređaju promjera $\varnothing 20 \mathrm{~cm}$ i visine $\mathrm{H}=20 \mathrm{~cm}$. U njemu su ugrađeni uzorci visine $\mathrm{h}=8 \mathrm{~cm}$, izdizanjem oslonca $\mathrm{u}$ samom cilindru, tj. pomicanjem donje površine kod opterećenja (slika 1).

$\mathrm{Na}$ pripremljenim uzorcima određen je materijalni sastav otpada izražen sudjelovanjem mase osnovnih sastavnica (slika 2). 
Tablica 1 - Objedinjeni prikaz parametara stišljivosti [4]

\begin{tabular}{|c|c|c|c|c|c|c|}
\hline $\mathrm{rb}$ & referenca & $\mathrm{C}_{c}$ & $\mathrm{C}_{c}^{\prime}$ & $\mathrm{C}_{\alpha}$ & $\mathrm{C}_{\alpha}{ }^{\prime}$ & napomena \\
\hline $1 \mathrm{a}$ & Sowers, 1973 & $0.3-1.1$ & $0.1-0.37$ & $0.06-0.18$ & $0.02-0.06$ & za e $_{0}=2$ \\
\hline $2 a$ & Zoino, 1974 & & $0.15-0.33$ & & $0.013-0.03$ & \\
\hline $3 a$ & Converse, 1975 & & $0.25-0.3$ & & 0.07 & \\
\hline $4 a$ & Rao et al., 1977 & & $0.16-0.235$ & & $0.012-0.046$ & \\
\hline $5 a$ & Landva et al., 1984 & & $0.2-0.5$ & & $0.0005-0.029$ & \\
\hline $6 a$ & Oweis and Khera, 1986 & & $0.08-0.217$ & & $0.02-0.072$ & \\
\hline $7 a$ & $\begin{array}{c}\text { Bjarngard and Edgers, } \\
1990\end{array}$ & & & & $0.004-0.04$ & \\
\hline $8 a$ & Fassett et al., 1994 & & & & $<0.1$ & \\
\hline $9 a$ & Wall and Zeiss, 1995 & & $0.21-0.25$ & & $0.033-0.056$ & \\
\hline $10 a$ & Gabr and Valero, 1995 & $0.4-0.9$ & $0.2-0.23$ & $0.03-0.09$ & $0.015-0.023$ & $\begin{array}{c}e_{0}=1-3 \\
\text { starost otpada od } \\
15-30 \text { god. }\end{array}$ \\
\hline $11 a$ & $\begin{array}{c}\text { Boutwell and Fiore, } \\
1995\end{array}$ & & $0.09-0.19$ & & $0.006-0.012$ & \\
\hline $12 a$ & Stulgis, 1995 & & 0.16 & & 0.02 & \\
\hline $13 a$ & GeoSyntec, 1996 & & $0.35-0.55$ & $0.1-0.18$ & & $\begin{array}{c}\text { pov. analize na } \\
\text { odlagalištima u } \\
\text { USA }\end{array}$ \\
\hline $14 a$ & $\begin{array}{c}\text { Green and Jamenjad, } \\
1997\end{array}$ & & & & $0.01-0.08$ & \\
\hline $15 a$ & Oweis and Khera, 1998 & & & & $0.001-0.04$ & \\
\hline $16 b$ & Sharma et al., 1999 & & & $0.02-0.07$ & & \\
\hline $17 a$ & Landva et al., 2000 & & $0.17-0.24$ & & $0.01-0.016$ & $\gamma=7.6-10.4 \mathrm{kN} / \mathrm{m}^{3}$ \\
\hline $18 a$ & Qiau et al., 2001 & & $0.17-0.36$ & & $0.01-0.1$ & \\
\hline $19 b$ & Machado et al., 2002 & $0.52-0.92$ & 0.21 & $0.021-0.044$ & $0.012-0.016$ & $\sigma_{v}^{\prime}=60-640 \mathrm{kPa}$ \\
\hline $20 \mathrm{~b}$ & Park et al., 2002 & & & & $0.014-0.063$ & svježi otpad \\
\hline $21 a$ & Hossain et al., 2003 & & $0.16-0.37$ & $0.07-0.22$ & $0.015-0.030$ & $e_{0}=2-2.8$ \\
\hline $22 a$ & Liu Rong et al., 2003 & & $0.13-0.46$ & & & $e_{0}=3.5-5.0$ \\
\hline $23 a$ & Chen and Ke, 2003 & & 0.354 & & & $\mathrm{e}_{0}=3.8$ \\
\hline $24 b$ & Marques et al., 2003 & & $0.073-0.132$ & & & $\begin{array}{c}\text { terenska } \\
\text { promatranja }\end{array}$ \\
\hline $25 b$ & Anderson et al., 2004 & & $0.17-0.23$ & & $0.024-0.030$ & $\begin{array}{c}\text { terenska } \\
\text { promatranja }\end{array}$ \\
\hline $26 b$ & Lewis et al., 2004 & & & & $0.014-0.045$ & $\begin{array}{c}\text { meh. tretiran (din. } \\
\text { zbijan; usitnjen) }\end{array}$ \\
\hline $27 c$ & Vilar and Carvalho, 2004 & $0.52-0.92$ & $0.18-0.23$ & $0.021-0.044$ & $0.012-0.016$ & $\begin{array}{c}\text { starost otpada oko } \\
15 \text { god }\end{array}$ \\
\hline $28 \mathrm{c}$ & Singh, 2008 & & 0.42 & & $0.0005-0.15$ & $\sigma_{V}^{\prime}=22-180 \mathrm{kPa}$ \\
\hline $29 a$ & Chen et al., 2009 & $0.23-1.42$ & $0.084-0.313$ & & & $e_{0}=1.1-4.2$ \\
\hline 30 & Rakić, 2013 & $0.19-0.35$ & $0.074-0.119$ & $\begin{array}{c}\left(\mathrm{C}_{\alpha}\right)_{\min } \\
0.001-0.024 \\
\left(\mathrm{C}_{\alpha}\right)_{\max } \\
0.024-0.107\end{array}$ & $\begin{array}{c}\left(C_{\alpha}{ }^{\prime}\right)_{\min } \\
0.0011-0.0089 \\
\left(C_{\alpha}{ }^{\prime}\right)_{\max } \\
0.0086-0.0509\end{array}$ & $\begin{array}{c}\text { starost oko } 15 \text { god } \\
\mathrm{e}_{0}=1.56-1.94\end{array}$ \\
\hline 31 & Rakić, 2013 & $0.27-0.38$ & $0.102-0.125$ & $\begin{array}{c}\left(\mathrm{C}_{\alpha}\right)_{\min } \\
0.003-0.025 \\
\left(\mathrm{C}_{\alpha}\right)_{\max } \\
0.011-0.093\end{array}$ & $\begin{array}{c}\left(C_{\alpha}{ }^{\prime}\right)_{\min } \\
0.0012-0.0082 \\
\left(C_{\alpha}{ }^{\prime}\right)_{\max } \\
0.0038-0.0302\end{array}$ & $\begin{array}{l}\text { starost oko } 40 \text { god } \\
\quad e_{0}=1.61-2.06\end{array}$ \\
\hline 32 & Rakić, 2013 & 0.425 & 0.159 & $\begin{array}{c}\left(\mathrm{C}_{\alpha}\right)_{\min } \\
0.018-0.027 \\
\left(\mathrm{C}_{\alpha}\right)_{\max } \\
0.047-0.061\end{array}$ & $\begin{array}{c}\left(C_{\alpha}{ }^{\prime}\right)_{\min } \\
0.0068-0.0102 \\
\left(C_{\alpha}{ }^{\prime}\right)_{\max } \\
0.0174-0.0228\end{array}$ & $\begin{array}{l}\text { Izmiješani otpad } \\
\quad \mathrm{e}_{0}=1.68\end{array}$ \\
\hline
\end{tabular}

a - podatke su prezentirali Chen i dr. 2009 [5]

b - podatke su prezentirali Sharm i dr. 2007 [6]

c - podatke je prezentirao Singh, 2008 [7] 


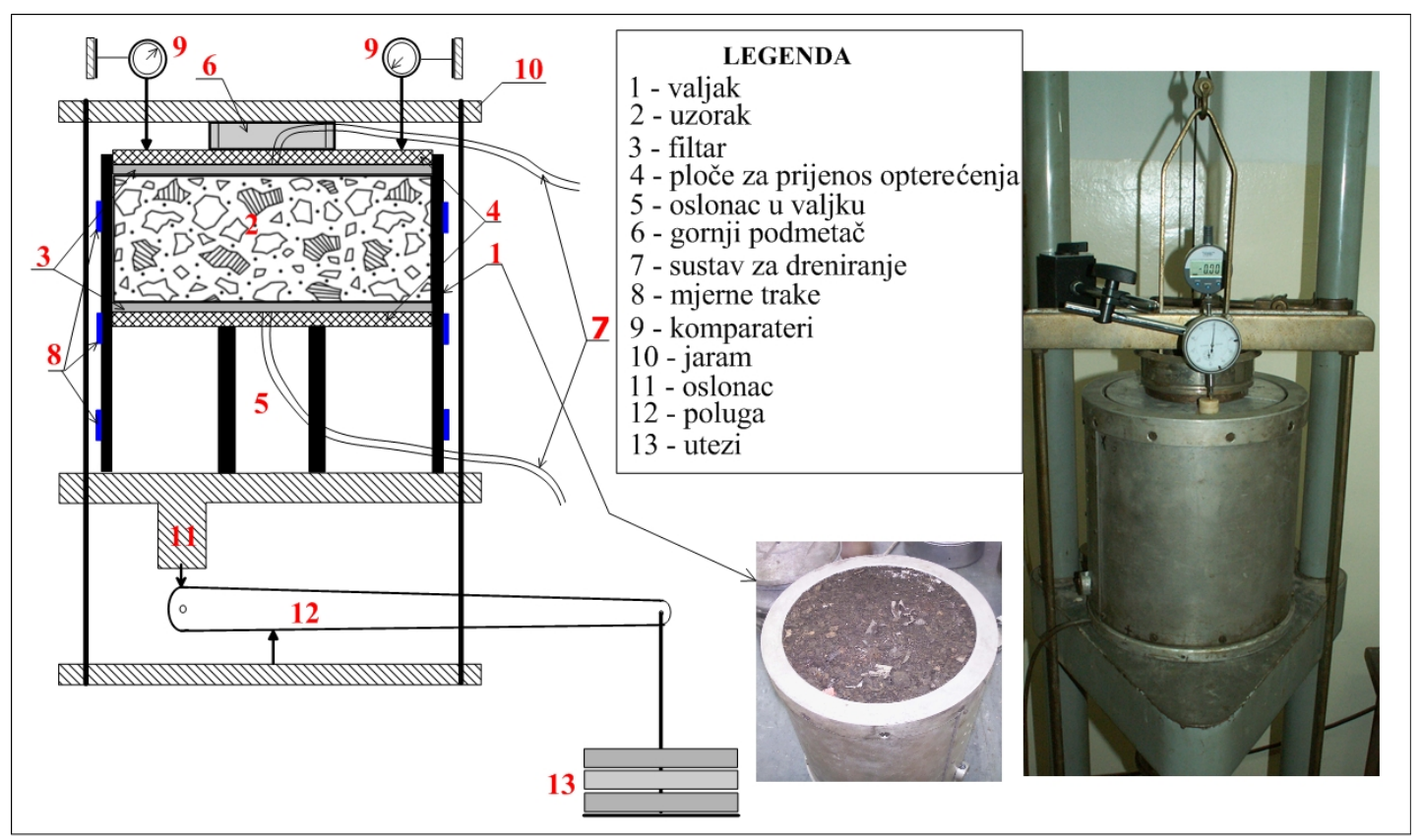

Slika 1 - Shematski prikaz edometarskog uređaja i sustava za opterećenje

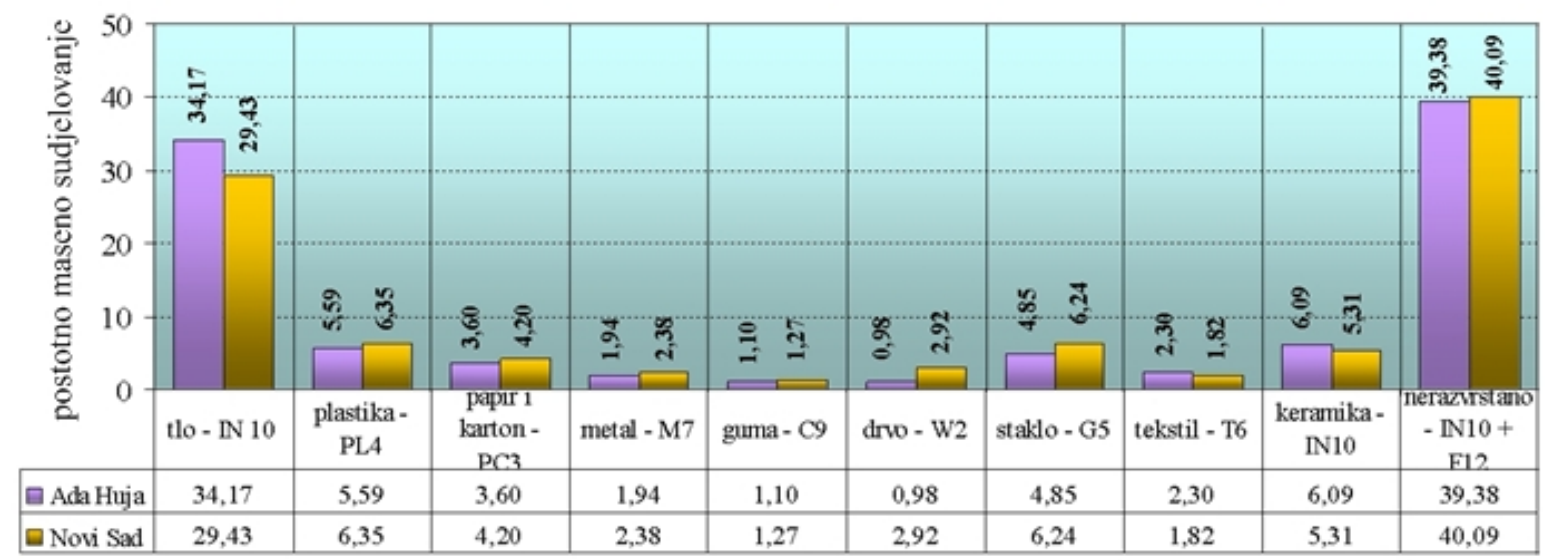

\section{Slika 2 - Materijalni sastav komunalnog otpada koji je korišten za ispitivanje [4]}

Kao što se vidi, otpad sadrži znatan postotak nerazvrstanog i zemljanog materijala (bilo od materijala koji je korišten za prekrivanje ili zbog poodmakle faze razgradnje), što je uobičajeno za stari otpad već formiranih odlagališta u kojima je proces biodegradacije u poodmakloj fazi. Formirane su dvije serije (A i B) od po 4 uzorka, tj. za seriju A korišten je otpad s odlagališta Ada Huja, a za seriju B korišten je otpad s odlagališta u Novom Sadu. Uzorci su formirani s različitim zapreminskim težinama, $\gamma=9.5,10.0,10.5$ i $11.0 \mathrm{kN} / \mathrm{m}^{3}$, koje su tipične za većinu odlagališta koja sadrže veći postotak tla [8]. Kod svih uzoraka opterećenja su nanošena stupnjevito, a izabrane su sljedeće vrijednosti vertikalnih naprezanja: 10-30-50-150 kPa (100 kPa za seriju B), koje su konstantno održavane. Ukupno trajanje ispitivanja za uzorke iz serija A iznosilo je 74 dana, a za uzorke iz serije B 161 dan (slika 3). 


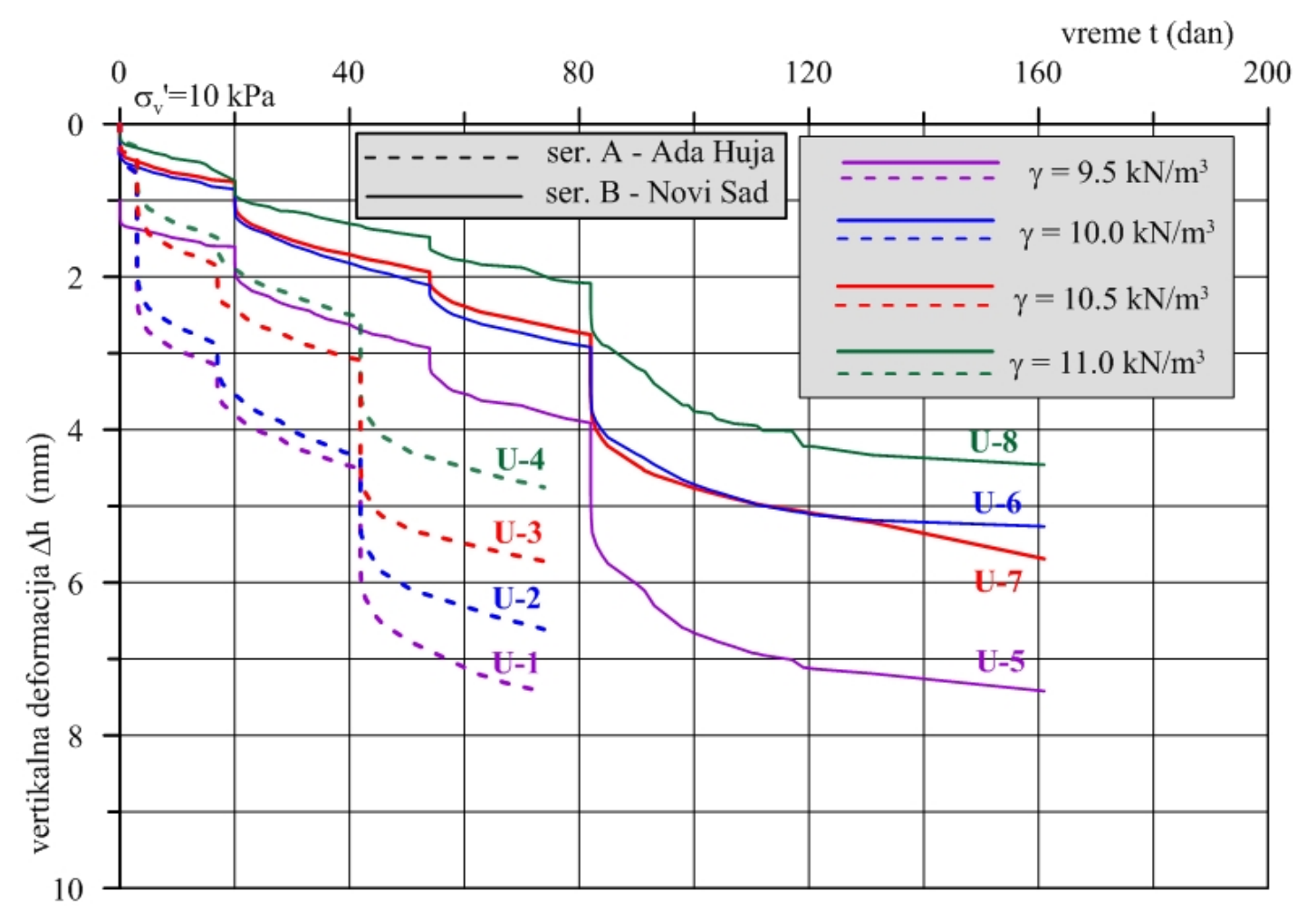

Slika 3 - Zavisnost vrijeme-deformacija za uzorke iz serija A i B [4]

\section{$4 \quad$ Rezultati laboratorijskih ispitivanja}

Tijekom ispitivanja prikupljani su podatci o vertikalnom vremenskom slijeganju zbog djelovanja naprezanja, kao i osnovne - početne fizičke karakteristike uzorka. Neki od rezultata ispitivanja za obje serije uzoraka, ovisno o stupnju opterećenja, prikazani su na slici 4. Rezultati pokazuju da većina krivulja u ranom vremenskom periodu ima ustaljeni, relativno blagi trend, koji se kasnije značajno povećava s vremenom. Znatno veći nagib u poodmakloj fazi kompresije pripisuje se većem raspadanju otpada i postupnim slabljenjem čvrstog kostura koji se u određenom trenutku ne može suprotstaviti vlastitoj težini, čime dolazi do propadanja - urušavanja. Povećanje pora i česta urušavanja za vrijeme degradacije otpada, jedan su od glavnih faktora koji utječu na sekundarnu kompresiju [4].

$\mathrm{Na}$ osnovi analize rezultata prikazanih na dijagramima, indeks sekundarne kompresije je izračunat tako što je za početak sekundarne kompresije usvojeno vrijeme od oko $15 \mathrm{~min}$. Treba naglasiti da su i drugi istraživači uvodili slične pretpostavke o trajanju primarne i početku sekundarne kompresije [7], [9]. Vrijednosti indeksa i modificiranog indeksa sekundarne kompresije su određene za sve stupnjeve opterećenja, posebno za blaži, a posebno za strmiji dio krivulje (Tablica 1). S obzirom na karakter deformacija, s blažeg dijela dijagrama određene su njihove minimalne vrijednosti $\left(C_{\alpha \min }\right.$ i $\left.C^{\prime}{ }^{\prime}{ }_{\text {min }}\right)$, dok su sa strmijeg dijela dijagrama, koji po pravilu počinje nakon 1 do 5 dana, određene maksimalne vrijednosti $\left(C_{\alpha \max }\right.$ i $\left.C^{\prime}{ }_{\text {amax }}\right)$. 


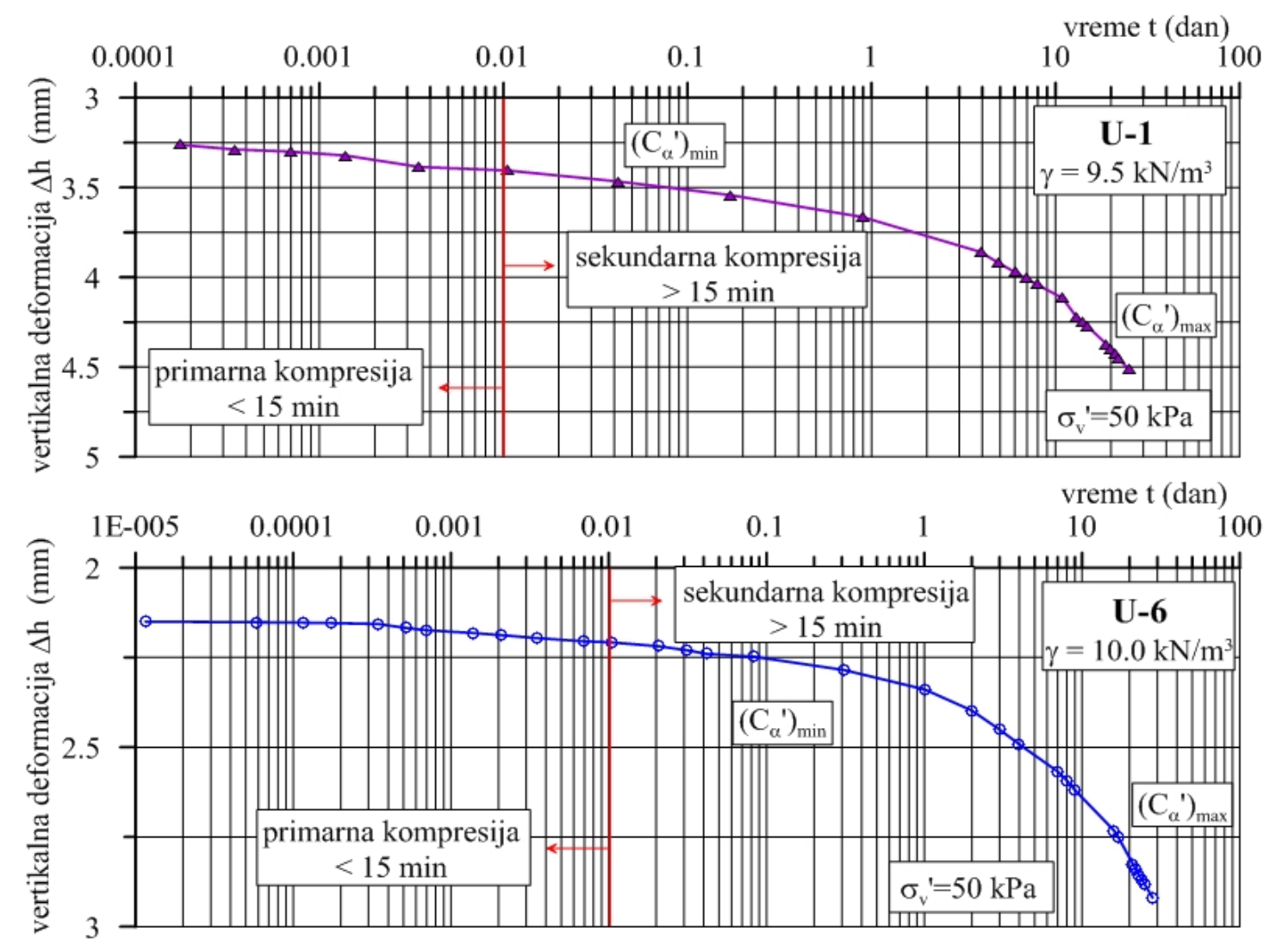

Slika 4 - Dijagrami kompresije za stupanj opterećenja $\sigma_{v}{ }^{\prime}=50$ kPa (U-1 serije A; U-6 serija B)

\section{Primjena različitih modela u analizi slijeganja komunalnog otpada}

Razlikuju se tri stupnja slijeganja komunalnog otpada,: inicijalno, primarno i sekundarno. Inicijalno slijeganje javlja se prilikom direktnog nanošenja opterećenja i rezultat je trenutačnog smanjenja pora. Primarno slijeganje javlja se u periodu od 4-5 tjedana nakon nanošenja opterećenja, poslije čega postaje dominantan učinak sekundarne kompresije. Sekundarna kompresija je rezultat puzanja i biološkog raspadanja i ne zavisi od opterećenja. Općenito, slijeganje deponije se analizira kroz dvije faze. Prva faza se odvija tijekom odlaganja otpada i može se poistovijetiti s primarnom konsolidacijom, a druga nastupa zbog sloma fragmenata materijala, biokemijske dekompozicije i mehaničkog puzanja u dugom vremenskom periodu, a odgovara sekundarnoj kompresiji. Pritom treba napomenuti da najveći dio ukupnog slijeganja čini upravo sekundarna kompresija, zbog čega se pri analizi slijeganja često daje prioritet indeksu sekundarne kompresije [10]. Sa svrhom prognoziranja slijeganja komunalnog otpada, više autora opisivalo je mehanizme prema kojima su formirani različiti modeli slijeganja. $\mathrm{Na}$ osnovi rezultata laboratorijskih ispitivanja komunalnog otpada ili pak terenskih mjerenja na samim odlagalištima, izdvojene su četiri osnovne grupe modela:

- modeli zasnovani na tradicionalnoj Terzaghijevoj teoriji konsolidacije tla koja uključuje sekundarnu kompresiju, a koristi geomehaničke karakteristike otpada

- empirijski modeli, zasnovani na podatcima terenskih i laboratorijskih ispitivanja, s primjenom teorije brzine procesa slijeganja

- reološki modeli za tla, primijenjeni na komunalni otpad i

- modeli slijeganja koji uključuju biodegradaciju otpada.

Kao najčešće primjenjivan model, zasnovan na teoriji konsolidacije, navodi se Sowersov model [11]. Prema njemu se slijeganje komunalnog otpada odvija u dvije osnovne faze: u početku se poistovjećuje s primarnom kompresijom u fazi odlaganja, a kasnije, nakon određenog vremenskog perioda, do izražaja dolazi sekundarna 
kompresija. Primarno slijeganje se po pravilu obavi tijekom prva dva do tri mjeseca nakon odlaganja otpada. Za analizu se koriste metode koje se primjenjuju i u mehanici tla, tako da se primarno slijeganje određuje kao:

$$
\Delta s_{c}=\frac{C_{c} \cdot H_{0}}{1+e_{0}} \cdot \log \left(\frac{p_{0}^{\prime}+\Delta \sigma}{p_{0}^{\prime}}\right)=C^{\prime}{ }_{c} \cdot H_{0} \cdot \log \left(\frac{p_{0}^{\prime}+\Delta \sigma}{p_{0}^{\prime}}\right)
$$

gdje je:

$H_{0}$ početna debljina analiziranog sloja otpada

$e_{0} \quad$ početni koeficijent pora sloja otpada (prije slijeganja)

$\mathrm{C}_{c}$ indeks primarne kompresije

$C_{c}^{\prime}$ modificirani indeks primarne kompresije

$p_{0}^{\prime}$ efektivno vertikalno naprezanje zbog prethodno nanesenog opterećenja u sredini sloja koji se sliježe

$\Delta \sigma$ dopunsko opterećenje zbog težine otpada u sredini sloja koji se sliježe.

Za razliku od tla, kod deponija komunalnog otpada, nakon primarnog slijedi dugotrajno sekundarno slijeganje koje se odvija zbog kemijske i biološke razgradnje otpada. Slijeganje koje nastaje zbog sekundarne kompresije izražava se sljedećom jednadžbom:

$$
\Delta s_{\alpha}=\frac{C_{\alpha} \cdot H_{0}}{1+e_{0}} \cdot \log \left(\frac{t_{2}}{t_{1}}\right)
$$

gdje je:

$t_{1}$ i $t_{2}$ vremena (u god.) koja ograničavaju interval za koji se analizira slijeganje

$\mathrm{C}_{\alpha}$ indeks sekundarne kompresije.

Na osnovi jednadžbi (5) i (6) izračunava se ukupno slijeganje:

$$
\Delta s=C^{\prime}{ }_{c} \cdot H_{0} \cdot \log \left(\frac{p_{0}^{\prime}+\Delta \sigma}{p^{\prime}{ }_{0}}\right)+C^{\prime}{ }_{\alpha} \cdot H_{0} \cdot \log \left(\frac{t}{t_{c}}\right)
$$

gdje je:

$C_{\alpha}^{\prime}$ modificirani indeks sekundarne kompresije

$t_{c} \quad$ vrijeme završetka primarnog slijeganja

$t \quad$ analizirano vrijeme slijeganja $\left(t>t_{c}\right)$.

Ovaj model su naknadno razradili Bjarngard i Edgers [12] mjerenjima na odlagalištima. Autori su predložili izraz za proračun ukupnog slijeganja, gdje je nužno poznavanje početnog prosječnog vertikalnog naprezanja pa na taj način i zapreminske težine otpada u odlagalištu:

$$
\frac{\Delta s}{H_{0}}=C^{\prime}{ }_{c} \cdot \log \left(\frac{p^{\prime}{ }_{0}+\Delta \sigma}{p^{\prime}{ }_{0}}\right)+C^{\prime}{ }_{\alpha 1} \cdot \log \left(\frac{t_{2}}{t_{1}}\right)+C^{\prime}{ }_{\alpha 2} \cdot \log \left(\frac{t_{3}}{t_{2}}\right)
$$

gdje je:

$\Delta s \quad$ slijeganje komunalnog otpada

$H_{0} \quad$ početna debljina analiziranog sloja otpada

$p_{0}^{\prime} \quad$ početno prosječno efektivno vertikalno naprezanje

$\Delta \sigma \quad$ prirast vertikalnog naprezanja zbog težine otpada

$\mathrm{C}_{c}^{\prime} \quad$ modificirani indeks primarne kompresije

$C_{\alpha 1}^{\prime}{ }_{\alpha 1} C_{\alpha 2}^{\prime}$ modificirani indeksi sekundarne kompresije (srednji i dugoročni)

$t_{1}, t_{2} i t_{3}$ vremena (god.) koja ograničavaju intervale za koje se određuje slijeganje (početno, srednje i dugotrajno). 
U uporabi su i određeni empirijski modeli, izraženi matematičkim relacijama preko logaritamske [13], hiperbolične [14] i eksponencijalne funkcije puzanja [15]. Također se koriste i reološki modeli koji su služli za prognozu slijeganja tla, odnosno treseta (Gibson i Lo, 1961), zbog dugoročne sekundarne kompresije. Ovaj model iskoristili su Edil i dr. [16], kao i El Fadel i dr. [15] za prognozu slijeganja komunalnog otpada na odlagalištu. Postojeći modeli, i pored stalnog usavršavanja, nedovoljno uzimaju u obzir prisutnost organske frakcije i faktore koji utječu na raspadanje, što je veliki nedostatak. Budući da se znatan dio ukupnog slijeganja deponije može pripisati sekundarnoj kompresiji, teži se poboljšanju ovih modela da se dobiju što točnija slijeganja i da se pritom uzima u obzir biodegradacija. Park i Lee [17] su prikazali matematički model koji uključuje i proces raspadanja biorazgradivog otpada s geotehničkog stajališta, ukazujući na cjelokupno ponašanje komunalnog otpada prilikom slijeganja.

U okviru ovoga rada, analiza slijeganja provedena je na primjeru jednog dijela lokacije komunalne deponije grada Novog Sada, gdje je odlaganje otpada započelo 1980. godine., a završeno 1999. godine. Na osnovi izvršenih geotehničkih istraživanja terena, formiran je opći geotehnički model koji je iskorišten za analizu slijeganja (slika 5). Analiza slijeganja provedena je primjenom parametara deformabilnosti, za koje su uspostavljene određene zavisnosti temeljem rezultata laboratorijskih ispitivanja $\left(C_{c}=f\left(e_{0}\right) ; C_{\alpha \max , \min }=f\left(e_{0} ; \sigma_{v}^{\prime}\right)\right)$, a provedena je korištenjem odabranih modela iz opisanih grupa, a to su:

- $\quad$ modeli koji su zasnovani na teoriji konsolidacije, i to Sowersov model i model Bjarngard i Edgers [11] i [12]

- empirijski modeli: logaritamska funkcija Yen i Scanlon [13], hiperbolična funkcija Ling i dr. [14] i eksponencijalna funkcija El-Fadel i dr. [15]

- $\quad$ reološki model Edil i dr. [16] i El Fadel i dr. [15] i

- $\quad$ biološki model Park i Lee [17].

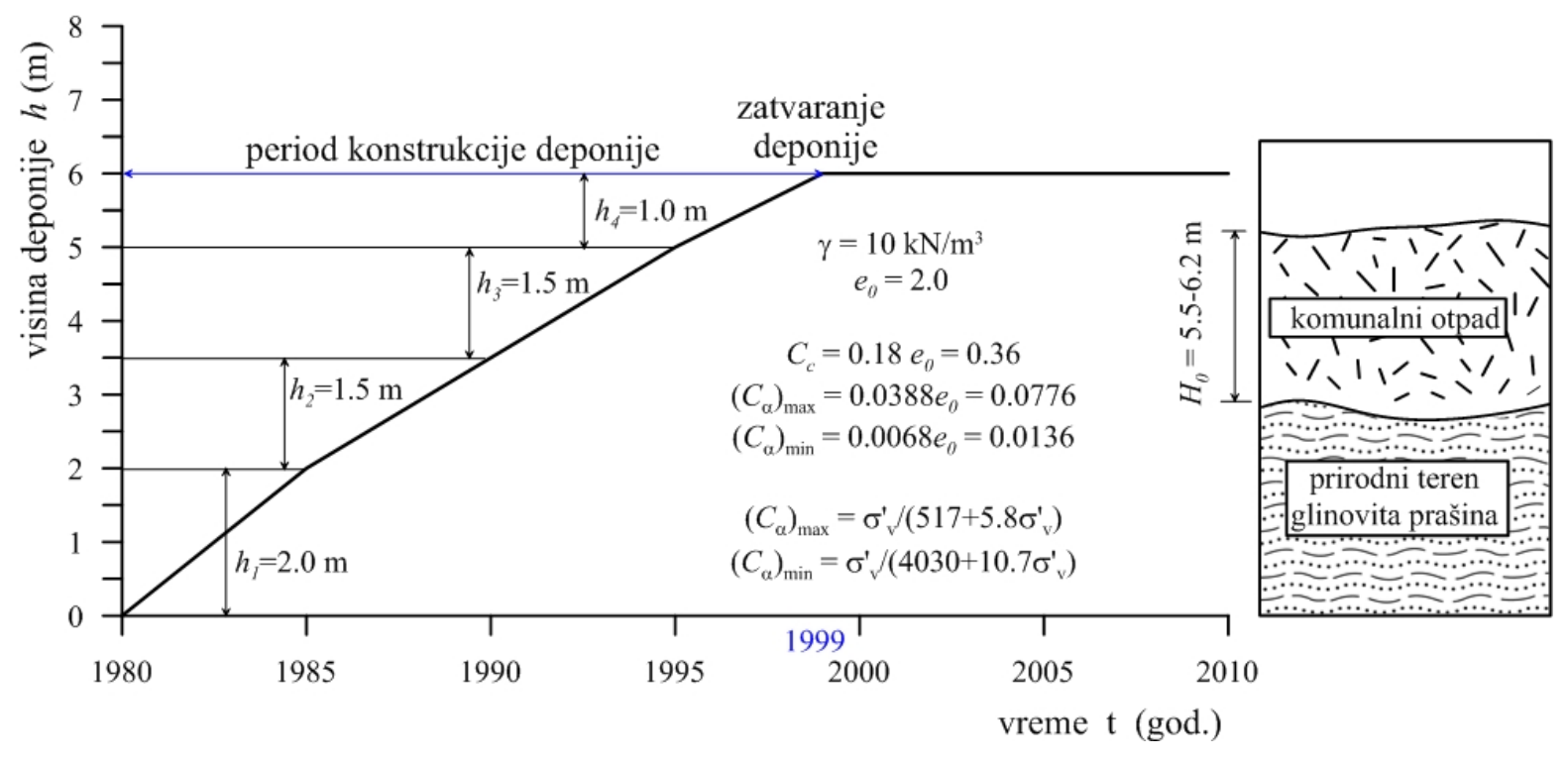

Slika 5 - Usvojeni geotehnički model lokacije prema kojemu je izvršena analiza slijeganja

Za modele u kojima figuriraju parametri koji nisu obuhvaćeni istraživanjima (empirijski, reološki i biološki), vrijednosti su usvojene na osnovi preporuka autora.

$\mathrm{Na}$ slici 6 skupno su prikazani dijagrami izračunatih vrijednosti slijeganja primjenom korištenih modela [4]. Primjećuju se značajne razlike izračunatih slijeganja. Najveća odstupanja u odnosu na uprosječene vrijednosti izračunatih slijeganja od $\Delta s_{\text {sred }} \approx 44.5 \mathrm{~cm}$, dobivena su korištenjem empirijskih modela (logaritamskog i hiperboličnog tipa), kao i primjenom reološkog modela Gibsona i Loa. Treba naglasiti da je u ovim modelima slijeganje računano s usvojenim parametrima, na osnovi prijedloga njihovih autora. U odnosu na uprosječenu vrijednost izračunatih slijeganja, korištenjem različith modela, najpribližnije vrijednosti dobivene su korištenjem modela u kojima figuriraju parametri dobiveni laboratorijskim ispitivanjima komunalnog otpada $s$ analizirane lokacije. Promatrano u odnosu na početnu visinu analiziranog dijela deponije od $\mathrm{H}_{0}=6.0 \mathrm{~m}$, slijeganje je iznosilo od $3.3 \%$ pa do $11.2 \%$. 


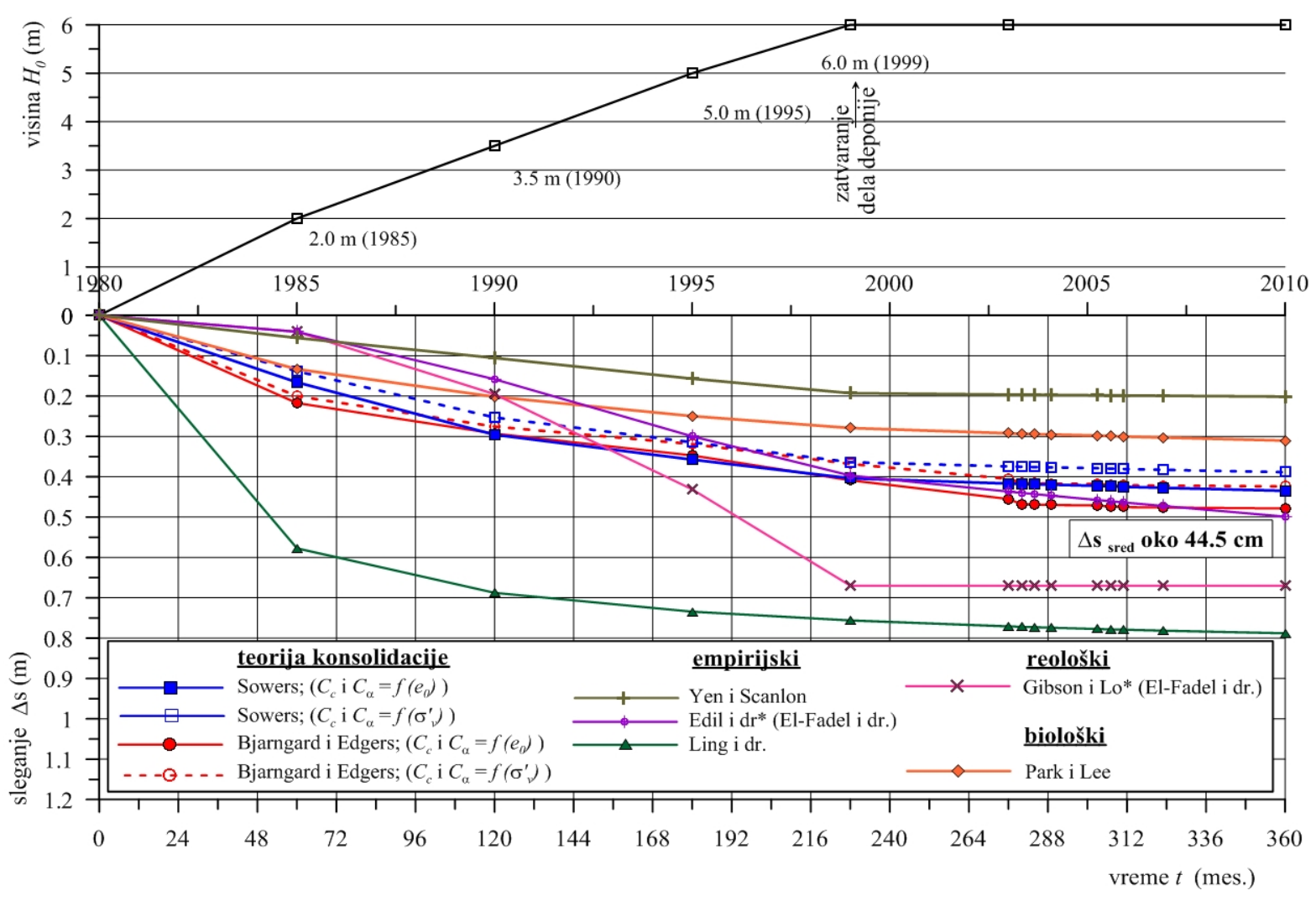

Slika 6 - Skupni prikaz izračunatih slijeganja korištenjem različitih modela [4]

\section{Zaključak}

Analiza slijeganja odlagališta otpada predstavlja jedan od najvećih geotehničkih problema kada je u pitanju istraživanje komunalnog otpada. Pored poteškoća koje se odnose na način odlaganja, izbor materijala i pripreme uzoraka, korištene metode i uređaje za ispitivanje, poseban utjecaj na slijeganje otpada pripisuje se heterogenosti materijala, vremenu i biodegradacijskim procesima koji uvjetuju promjenu faznog sastava. Utjecaj vremena na slijeganje komunalnog otpada autori su analizirali kroz različite mehanizme, prema kojima su predlagani i različiti modeli slijeganja.

Rezultati slijeganja koji su prikazani u radu, ukazali su na značajne razlike zavisno od primijenjenih modela. Minimalna $\Delta s_{\text {min }}^{\prime}=19.64 \mathrm{~cm}\left(3.3 \%\right.$ u odnosu na početnu visinu otpada $\left.H_{0}=6.0 \mathrm{~m}\right)$, kao i maksimalna slijeganja $\Delta s_{\text {max }}^{\prime}=77.08 \mathrm{~cm}$ (12.8\% početne visine), dobivena su korištenjem empirijskih modela, s parametrima koje su predlagali njihovi autori. Ovakva rasipanja nisu neuobičajena, jer su prilikom proračuna slijeganja komunalnog otpada, primjenom različitih modela, velika odstupanja (0.8 \% - 67.2 \%) dobivali i drugi autori [18]. Ovo potvrđuje poznatu činjenicu da do danas još uvijek nije razvijen generalni model koji uključuje sve aspekte utjecaja na slijeganje komunalnog otpada. Bez obzira na to, u modelima u kojima figuriraju parametri stišljivosti, analiza slijeganja će svakako biti preciznija ako se za određivanje parametara koriste konvencionalne metode ispitivanja, bez obzira na izrazitu heterogenost komunalnog otpada. 


\section{Literatura}

[1] Fassett, J.B., Leonards, G.A. \& Repetto, P.C. (1994). Geotechnical Properties of Municipal Solid Waste and Their Use in Landfill Design, WasteTech '94 - Landfill Technology Conference, Charleston, South Carolina, USA, 1-32.

[2] Coumoulos, D. G. \& T. P. Koryalos, 1999. Prediction of long-term settlement behaviour of landfill covers after closure, Proceedings of the 7th International Landfill Symposium, Sardinia '99, S. Margherita di Pula, CISA, Italy, 505-512.

[3] Machado, S.L., Carvalho, M.F. \& Vilar, O.M. (2002). Constitutive Model for Municipal Solid Waste, Journal of Geotechnical and Geoenvironmental Engineering 128(11), 940-951.

[4] Rakić, D. (2013). Konstitutivne zavisnosti komunalnog otpada sa deponija u Srbiji, Doktorska disertacija, Univerztitet u Beogradu, Rudarsko-geološki fakultet Beograd, str. 458.

[5] Chen, Y.M., Zhan, L.T. \& Wei, H.Y. (2009). Aging and compressibility of municipal solid wastes. Waste Management, 29(1), 86-95.

[6] Sharma, H.D. \& Anirban De. (2007). Municipal solid waste landfill settlement: postclosure perspectives, Journal of Geotechnical and Geoinveronmental Engineering, Vol. 133, No. 6, 619-629.

[7] Singh, M.K. (2008). Characterization of stress-deformation behaviour of municipal solid waste, Ph.D. thesis, University of Saskatchewan, Saskatoon, Canada, 292.

[8] Zekkos, D.P., Bray, J.D., Kavazanjian, E., Matasovic, N., Rathje, E.M., Riemer, M.F. \& Stokoe, K.H. (2006). Unit weight of municipal solid waste, Journal of Geotechnical and Geoenvironmental Engineering, ASCE, 132(10), 250-1261.

[9] Landva, A.O., Valsangkar, A.J. \& Pelkey, S.G. (2000). Lateral earth pressure at rest and compressability of municipal solid waste, Canadian Geotechnical Journal, 37(No. 6), 1157-1165.

[10] Rakić, D., Čaki, L. \& Ljubojev, M. (2011). Deformable characteristics of the old municipal solid waste sites with Ada Huja, Belgrade - Serbia, TTEM - Technics Technologies Education Management, Volume 6, No 1 , $52-60$.

[11] Sowers, G.F. (1973). Settlement of waste disposal fills, Proceedings of the eighth international conference on soil mechanics and foundation engineering, Moscow, Vol. 2, 207-210.

[12] Bjangard A. \& Edgers L. (1990). Settlement of municipal solid waste landfills, Proceedings, 13 Annual Madison Waste Conference, 192-205.

[13] Yen, B.C. \& Scanlon, B.S. (1975). Sanitary landfill settlement rates, Journal Geotechnical Engineering, Vol. 101(5), 475-487.

[14] Ling, H. I., Leshchinsky, D., Mohri, Z. \& Kawabata, T. (1998). Estimation of municipal solid waste landfill settlement, Journal Geotechnical and Geoenvironmental Engineering, ASCE, 124, 21-28.

[15] El-Fadel, M., Shazbak, S., Saliby, E. \& Leckie, J. (1999). Comparative assessment of settlement models for municipal solid waste landfill applications, Waste Management Res., Vol. 17(5), 347-368.

[16] Edil, T.B., Ranguette, V.J. \& Wuellner, W.W. (1990). Settlement of municipal waste, Geotechnics of Waste Fills - Theory and Practise, ASTM STP 1070, Landva, A.O. and Knowles, G.D., eds., American Society for Testing and Materials, Philadelphia, USA, 225-239

[17] Park, H.I. \& Lee, S.R. (1997). Long-term settlement behavior of landfills with refuse decomposition, Journal of Resource Management and Technology 24 (4), 159-165.

[18] Babu G.L.S., Reddy K.R. \& Chouksey S.K. (2010). Constitutive model for municipal solid waste incorporating mechanical creep and biodegradation-induced compression, Waste Management, 30, 11-22. 